ENCYCLOPÉDIE Encyclopédie berbère

BERBERE

$10 \mid 1991$

10 | Beni Isguen - Bouzeis

\title{
Bou Noura
}

\section{Y. Bonête}

\section{OpenEdition}

Journals

Édition électronique

URL : http://journals.openedition.org/encyclopedieberbere/1794

DOI : 10.4000/encyclopedieberbere.1794

ISSN : 2262-7197

\section{Éditeur}

Peeters Publishers

\section{Édition imprimée}

Date de publication : 1 décembre 1991

Pagination : 1577

ISBN : 2-85744-549-0

ISSN : 1015-7344

Référence électronique

Y. Bonête, «Bou Noura », Encyclopédie berbère [En ligne], 10 | 1991, document B94, mis en ligne le 01 juin 2013, consulté le 25 septembre 2020. URL : http://journals.openedition.org/encyclopedieberbere/ 1794 ; DOI : https://doi.org/10.4000/encyclopedieberbere.1794

Ce document a été généré automatiquement le 25 septembre 2020

(c) Tous droits réservés 


\section{Bou Noura}

\section{Y. Bonête}

1 La fondation de Bou Noura remonterait à 1046 ou à 1048. La destruction de cette ville se situe mal dans le temps, vers 1250-1251; elle aurait été le résultat soit d'une guerre soutenue sans succès contre les autres villes pour un différent avec Melika, soit d'un conflit civil qui aurait entraîné l'exode massif de la population vers Melika. Quoi qu'il en soit la partie haute de la colline, où devait se situer cette ville de Bou Noura, est restée en ruine pendant des siècles, seule la salle de prière de la mosquée, au sommet, étant régulièrement entretenue et repeinte. Le minaret en revanche est resté brisé à mi-hauteur jusqu'en 1983. Cette année-là des travaux ont été entrepris pour le restaurer dans sa hauteur normale et pour rétablir les dépendances de la mosquée (salle des ablutions...). Lors de ces travaux, la porte d'accès à la salle de prière qui se trouvait dans l'axe de la nef centrale a été déplacée et placée dans l'axe de la nef de gauche. Le déplacement de cette porte est curieux. Bou Noura est une ville qui ne se prévaut ni de rigueur, ni de sainteté. Elle a de tout temps occupé dans la confédération un rang assez modeste.

\section{INDEX}

Mots-clés : Sahara, Villes 